\title{
ODRĘBNOŚCI USTROJOWE GMIN UZDROWISKOWYCH
}

\section{WPROWADZENIE}

Problematykę odrębności ustrojowych gmin uzdrowiskowych należy rozpocząć konstatacja, że pod względem rozwoju regulacji prawnej ustawodawstwo uzdrowiskowe nakładało się na ustawodawstwo samorządowe, ale na obydwu poziomach rozwój ten nie przebiegał równolegle. Można zauważyć, że ustawodawstwo uzdrowiskowe wyprzedzało ustawodawstwo samorządowe, przyjmując, że początek tego ostatniego przypada na rok $1933^{1}$. Tymczasem pierwsza ustawą regulująca problematykę uzdrowiskową była ustawa z 23 marca $1922 \mathrm{r}$. o uzdrowiskach ${ }^{2}$, w której treści znajduje się szereg odniesień do ustroju samorządu terytorialnego, funkcjonującego w tym czasie na podstawie przepisów obowiązujacych w byłych państwach zaborczych ${ }^{3}$. W okresie obowiązywania znacznie mniej rozbudowanej ustawy z 17 czerwca 1966 r. o uzdrowiskach i lecznictwie uzdrowiskowym ${ }^{4}$ powiązanie uzdrowisk z samorządem było iluzoryczne, tak jak iluzoryczny był w owym czasie sam samorząd terytorialny. Anachroniczność ustawy z 1966 r. i jej swoiste oderwanie od struktur terenowych, związane z ówczesnymi realiami ustrojowymi, nie pozwoliły na ukształtowanie się koncepcji gminy uzdrowiskowej, a osiedla uzdrowiskowe, które mogły być wydzielone z obszaru gromady ${ }^{5}$, nie mogły być za takie uznane. W okresie obowiązywania ustawy z 1966 r. w wyniku przekształceń ustrojowych przywrócono samorząd terytorialny ${ }^{6}$, ale na dojrzała regulację wypełniająca postulat pojawienia się na mapie podziału administracyjnego kraju gmin uzdrowiskowych trzeba było jeszcze poczekać. Jednak już w tym czasie w nauce prawa analizowano problematykę odrębności ustrojowych gmin uzdrowiskowych ${ }^{7}$.

Obecnie pozycja prawna gmin uzdrowiskowych opiera się na dualistycznym modelu ustrojowoprawnym. Ogólny reżim ustrojowy określa ustawa o sa-

${ }^{1}$ Ustawa z 23 marca 1933 o częściowej zmianie ustroju samorządu terytorialnego, Dz. U. Nr 35, poz. 294 - tzw. ustawa scaleniowa.

${ }^{2}$ Dz. U. 1922, Nr 31, poz. 254.

${ }^{3}$ Maciejewski (2002): 273-275.

${ }^{4}$ Dz. U. 1966, Nr 23, poz. 150.

${ }^{5}$ Maciejewski (2002): 300.

${ }^{6}$ Ustawa z 8 marca 1990 r., Nr 16, poz. 95.

${ }^{7}$ Paczuski (1991): 87. 
morządzie gminnym ${ }^{8}$, ale ich status jako uzdrowisk oraz szczegółowe zadania wynikające z tego specjalnego statusu określa ustawa z 28 lipca 2005 r. o lecznictwie uzdrowiskowym, uzdrowiskach i obszarach ochrony uzdrowiskowej oraz o gminach uzdrowiskowych ${ }^{9}$. Jako regulacja prawna określajaca prawnoustrojowe i prawnomaterialne podstawy organizacji i funkcjonowania polskich uzdrowisk, ustawa ta jest aktem o dużej doniosłości, adekwatnym do celów i zadań idei zrównoważonego rozwoju ${ }^{10}$, co może uzasadniać pogląd, że aksjologiczną nadbudową modelu ustrojowoprawnego gmin uzdrowiskowych jest Konstytucja $\mathrm{RP}^{11}$.

Swoistego wzmocnienia ustrojowych podwalin ustawodawstwa uzdrowiskowego można doszukać się w art. 68 Konstytucji RP, który gwarantuje każdemu prawo do ochrony zdrowia. Prawu temu odpowiada obowiązek, spoczywający na organach gmin uzdrowiskowych, stworzenia warunków prowadzenia lecznictwa uzdrowiskowego, a to z kolei nie może być osiagnięte bez zapewnienia bardzo dobrego - z punktu widzenia poprawy zdrowia ludzkiego - stanu sanitarnego, środowiskowego i leczniczego uzdrowiska.

Występowanie na mapie podziału terytorialnego kraju gmin charakteryzujących się odrębnością ustrojową zapowiada systemowo art. 38 u.s.g., stanowiąc, że „odrębności ustroju gmin, które wykonują zadania o szczególnym charakterze, określają właściwe ustawy. Dotyczy to w szczególności gmin uzdrowiskowych"12. Z przepisu tego wynikaja dwie tezy: po pierwsze, szczególność zadań gmin uzdrowiskowych determinuje odrębny status ustrojowoprawny tych gmin, po drugie, odrębny status ustrojowy występuje przede wszystkim w gminach uzdrowiskowych, choć dyspozycja tego artykułu obejmuje także miasto stołeczne Warszawę, której ustrój i zadania uregulowane są w ustawie z 15 marca 2002 r. o ustroju miasta stołecznego Warszawy ${ }^{13}$ i - w określonych prawnie warunkach - także tzw. gminy górnicze. Warto w tym miejscu dodać, że tradycja prawna funkcjonowania miejscowości uzdrowiskowych wykształciła się w wielu państwach europejskich ${ }^{14}$.

Celem niniejszego artykułu jest wskazanie odrębności ustrojowych gmin uzdrowiskowych w Polsce, które skupiają się wokół następujących zagadnień: obszar i nazwa, zadania i opłata uzdrowiskowa, komisja uzdrowiskowa, statut oraz nadzór. Odrębności te nie czynią z gminy uzdrowiskowej gminy innej niż gmina standardowa, ale są konieczne do realizacji celów o szczególnym znaczeniu dla państwa i społeczeństwa.

${ }^{8}$ Dz. U. 2019, poz. 506 ze zm. (dalej jako: u.s.g.). Zob. na ten temat: Leoński (2006); Dolnicki (2016).

9 Dz. U. 2017, poz. 1056 ze zm. (dalej jako: u.l.u.g.u. lub „ustawa uzdrowiskowa”).

10 Paczuski (2015): 26.

11 Konstytucja Rzeczypospolitej Polskiej z 2 kwietnia 1997 r., Dz. U. 1997, Nr 78, poz. 483 ze zm.

${ }^{12} \mathrm{~W}$ Polsce istnieje obecnie 45 gmin uzdrowiskowych i wiele miejscowości o walorach potencjalnie uzdrowiskowych, <http://sgurp.pl/> [dostęp: 3.04.2019].

${ }_{13}$ Dz. U. 2015, poz. 1438 ze zm.

14 Nowak-Far (2010): 39. 


\section{PROBLEMATYKA OBSZAROWA}

Jeśli chodzi o samo pojęcie gminy uzdrowiskowej, po raz pierwszy posłużono się nim na mocy u.l.u.g.u., choć pierwsze wzmianki o powstaniu uzdrowisk w Polsce pochodza z XII i XIII w., kiedy to doszło do powstania takich uzdrowisk, jak: Cieplice, Lądek Zdrój i Szczawno ${ }^{15}$. Przez pojęcie gminy uzdrowiskowej rozumie się gminę, której obszarowi lub jego części został nadany status uzdrowiska w trybie określonym w ustawie (art. 2 pkt 2 u.l.u.g.u.). Z kolei uzdrowisko to obszar, na terenie którego prowadzone jest lecznictwo uzdrowiskowe, wydzielony w celu wykorzystania i ochrony znajdujacych się na jego obszarze naturalnych surowców leczniczych, spełniający warunki uzyskania statusu uzdrowiska (art. 2 ust. 3 w zw. z art. 34 ust. 1 u.l.u.g.u.). Gminą uzdrowiskowa jest zatem gmina w całości objęta statusem prawnym uzdrowiska, jak i gmina, której część posiada taki status. Nasuwa się wniosek, że jeśli na części gminy znajduje się uzdrowisko, cała gmina określana jest mianem gminy uzdrowiskowej.

Rozwinięcie problematyki obszarowej gmin uzdrowiskowych znajdziemy w art. 33 ust. 1 u.l.u.g.u., który stanowi, że granice obszaru, któremu został nadany status uzdrowiska albo status obszaru ochrony uzdrowiskowej, pokrywaja się z granicami administracyjnymi gmin, miast lub jednostek pomocniczych gmin. Można sądzić, że jeśli status uzdrowiska nie pokrywa się z granicami administracyjnymi gminy, rada gminy, uruchamiając procedurę prowadząca do nadania statusu uzdrowiska dla części obszaru gminy, wyraża zamiar ustanowienia jednostki pomocniczej dla tego obszaru. Ogólna zasada ustrojowa, zawarta w art. 5 u.s.g., wskazuje, że gmina może tworzyć jednostki pomocnicze. Z ustawy uzdrowiskowej wynika pewna odrębność, że ubieganie się o nadanie statusu uzdrowiska dla części obszaru gminy wiąże się z obligatoryjnym utworzeniem jednostki pomocniczej. Gmina może zatem uzyskać status uzdrowiska dla tej części swojego terytorium, która jest miastem, albo jej inną jednostką pomocniczą (np. sołectwem). Granice uzdrowiska moga pokrywać się też z granicami więcej niż jednej gminy, wówczas prawa i obowiązki przewidziane w ustawie wykonywane sa przez te gminy.

Kryterium wyodrębnienia gminy uzdrowiskowej i uzdrowiska stanowi nie tylko określone terytorium, ale przede wszystkim występowanie na tym obszarze surowców o walorach leczniczych i prozdrowotnych oraz spełnienie określonych ustawowo warunków. Jeśli zaś na danym terenie nie znajduja się zakłady lecznictwa uzdrowiskowego i urządzenia do prowadzenia lecznictwa uzdrowiskowego, ale występują odpowiednie warunki, jak klimat o właściwościach leczniczych oraz złoża naturalnych surowców leczniczych o potwierdzonych właściwościach leczniczych, wówczas zgodnie z treścią art. 34 ust. 2 u.l.u.g.u. - istnieje możliwość uzyskania przez dany obszar statusu

15 Sikora (2014): 107-124. 
obszaru ochrony uzdrowiskowej. Samo zaś rozróżnienie obszaru uzdrowiska i obszaru ochrony uzdrowiskowej jest na gruncie u.i.u.g.u. swoistą nowością ${ }^{16}$.

Ponadto odrębność gminy uzdrowiskowej tkwi w samej nazwie. Do nazwy miejscowości, w której granicach administracyjnych znajduje się obszar uzdrowiska, może być dodany odpowiednio wyraz „zdrój”, jeżeli podstawą leczenia uzdrowiskowego są wody lecznicze, lub wyraz „cieplice” bądź „uzdrowisko termalne", jeżeli podstawą leczenia uzdrowiskowego są wody termalne. Zmiany te odbywają się na zasadach określonych w ustawie z 29 sierpnia $2003 \mathrm{r}$. o urzędowych nazwach miejscowości i obiektów fizjograficznych ${ }^{17}$. Dodanie wyrazu do nazwy głównej identyfikuje gminę z jej właściwościami i będąc wyróżnikiem gminy posiadającej wody lecznicze lub wody termalne, stanowi dodatkowy bodziec dla gminnej administracji samorządowej w kierunku zapewnienia takiego poziomu warunków klimatycznych, środowiskowych i przyrodniczych miejscowości, który byłby godny miana „zdrój”.

\section{ODRĘBNOŚCI ZADANIOWE I OPŁATA UZDROWISKOWA}

O odrębności ustrojowej gmin uzdrowiskowych decyduje występowanie ponadstandardowych zadań własnych. Oprócz typowych dla każdej gminy zadań własnych, gmina uzdrowiskowa dysponuje „dodatkowym pakietem” zadań własnych, związanych z utrzymaniem funkcji leczniczych uzdrowiska. Te szczególne zadania są bezpośrednią przyczyną odrębności ustrojowoprawnej gmin uzdrowiskowych. Dotyczą one między innymi gospodarki terenami, z uwzględnieniem potrzeb lecznictwa uzdrowiskowego, ochrony złóż naturalnych surowców leczniczych oraz możliwości zabudowy w poszczególnych strefach ochrony uzdrowiskowej; ochrony warunków naturalnych uzdrowiska lub obszaru ochrony uzdrowiskowej oraz spełniania wymagań w zakresie dopuszczalnych norm zanieczyszczeń powietrza, natężenia hałasu, odprowadzania ścieków do wód lub do ziemi, gospodarki odpadami, emisji pól elektromagnetycznych; tworzenia warunków do funkcjonowania zakładów i urządzeń lecznictwa uzdrowiskowego oraz rozwoju infrastruktury komunalnej w celu zaspokajania potrzeb osób przebywajacych w gminie w celu leczenia uzdrowiskowego. W gminach uzdrowiskowych mamy więc do czynienia z dualistycznym charakterem zadań: gmina ta realizuje zadania własne zagwarantowane przez u.s.g. dla każdej gminy, ale z uwagi na swój szczególny charakter także zadania szczególne, związane z prowadzeniem na swoim terenie lecznictwa uzdrowiskowego.

Realizacja zadań własnych o szczególnym, uzdrowiskowym charakterze, zwiazanych z zachowaniem funkcji leczniczych uzdrowiska powoduje powstanie kolejnej odrębności gmin uzdrowiskowych, wyrażającej się w ich prawie do pobierania opłaty uzdrowiskowej. Opłata uzdrowiskowa jest odrębna, do-

${ }^{16}$ Korczak (2018): 112.

17 Dz. U. Nr 166, poz. 1612 ze zm. 
datkową opłatą lokalna, ściśle skierowaną do gmin uzdrowiskowych. Ten typ opłaty został wyodrębniony z dotychczas obowiązującej opłaty miejscowej ${ }^{18}$. W świetle art. 48 u.l.u.g.u. gmina uzdrowiskowa ma prawo do pobierania opłaty uzdrowiskowej „w celu realizacji zadań własnych zwiąanych z zachowaniem funkcji leczniczych uzdrowiska”, na zasadach określonych w przepisach odrębnych ${ }^{19}$. Niewątpliwie specyfika gmin uzdrowiskowych i wspomniany „dodatkowy pakiet” zadań własnych wiąże się z koniecznością ponoszenia większych wydatków. Środki pochodzące z opłaty uzdrowiskowej powinny być przeznaczane na prowadzenie monitoringu środowiska i poprawę jego jakości. Nieprawidłowości w tym zakresie obnażył raport NIK ${ }^{20}$, ponieważ żadna $\mathrm{z}$ kontrolowanych gmin nie prowadziła ewidencji wydatków pokrywanych z opłaty uzdrowiskowej. Postulować należy wzmocnienie systemu kontroli wykorzystania uzyskanych przez gminy opłat uzdrowiskowych i przeznaczanie ich na prowadzenie regularnego monitoringu środowiska i poprawę środowiskowych walorów uzdrowiska.

\section{KOMISJA UZDROWISKOWA JAKO OBOWIĄZKOWA KOMISJA STAŁA}

Wykonywanie zadań publicznych o szczególnym charakterze, a takimi sa zadania w zakresie prowadzenia lecznictwa uzdrowiskowego, wymaga wzmocnienia warstwy instytucjonalnej. Jedną z najważniejszych odrębności ustrojowych gmin uzdrowiskowych jest obowiązek powołania przez radę gminy stałej komisji uzdrowiskowej. Komisję uzdrowiskową rada gminy powołuje także w gminie posiadajaccej status obszaru ochrony uzdrowiskowej; w obu przypadkach określa jej przedmiot działania i skład osobowy. Warto w tym miejscu podkreślić, że komisje uzdrowiskowe nie były początkowo powiąane ściśle z samorządem terytorialnym. Na podstawie ustawy z 1922 r., która była jak na owe czasy swoistym fenomenem legislacyjnym, komisje uzdrowiskowe na podstawie art. 10 miały status podmiotu ,zarządzającego sprawami uzdrowiska” i jako takie dzieliły się na komisje zdrojowe, klimatyczne i kapielowe.

Ustrojowe podwaliny prototypów dzisiejszych komisji uzdrowiskowych stworzył art. 29 ustawy z 1922 r., ówczesne komisje uzdrowiskowe, dysponując istotnym zakresem władztwa administracyjnego, w niczym jednak nie przypominały dzisiejszej opiniodawczo-doradczej koncepcji tych komisji. Zreszta

18 Dudar (2006): 9.

19 Ustawa z 12 stycznia 1991 r. o podatkach i opłatach lokalnych (t.jedn.: Dz. U. 2018, poz. 1445). W myśl art. 17 ust. 1a rada gminy może wprowadzić opłatę uzdrowiskową. Opłatę uzdrowiskową pobiera się od osób fizycznych przebywających dłużej niż dobę w celach zdrowotnych, turystycznych, wypoczynkowych lub szkoleniowych w miejscowościach znajdujących się na obszarach, którym nadano status uzdrowiska.

${ }^{20}$ Raport Najwyższej Izby Kontroli z 29 grudnia 2016 r., <https:/www.nik.gov.pl/aktualnosci/nik-o-statusie-uzdrowisk.html> [dostęp: 6.04.2019]. 
sama koncepcja uzdrowiska była zgoła odmienna; mogło być ono w owym czasie własnością Skarbu Państwa lub własnością prywatną.

Komisję uzdrowiskową powoływano wówczas w każdym uzdrowisku uznanym za posiadający charakter użyteczności publicznej. Kompetencje ówczesnych komisji uzdrowiskowych wykraczały znacznie poza sferę samorządu terytorialnego, określane były mianem organu zarządzającego sprawami uzdrowiska na obszarze okręu ochrony sanitarnej. Poza obszernymi uprawnieniami przewidzianymi w art. 34 (np. zakładaniem szpitali, ustalaniem opłat uzdrowiskowych, wydawaniem przepisów sanitarnych, czuwaniem nad całością majątku uzdrowiska), komisje uzdrowiskowe mogły mieć również dodatkowo poruczony zakres działania w zastępstwie organów administracji gminnej lub państwowej. W pewnym sensie komisje uzdrowiskowe pełniły rolę organu administracji sanitarno-budowlanej w uzdrowisku, a sporządzając samodzielnie plan zabudowania i władczo decydujacc o kwestiach zabudowy miejscowości uzdrowiskowej i poprawiania jej walorów, także rolę administracji planistycznej. Inspekcyjno-policyjny charakter komisji uzdrowiskowych uzupełniały zadania w zakresie bezpieczeństwa zdrowia i policji budowlanej, a w sezonie kuracyjnym komisje uzdrowiskowe w granicach przyznanych gminom miejskim wykonywały także zadania policji bezpieczeństwa. Pod względem ustrojowym ówczesne komisje uzdrowiskowe miały silną pozycję, a ich zadania zbliżały je do organów o charakterze inspekcyjno-kontrolnym.

Przy tak szerokim zakresie zadań uzdrowisk uzasadniony był równie szeroki skład tych komisji, które tworzyli z głosem decydujacym: delegaci rządowi (kiedy właścicielem uzdrowiska był Skarb Państwa), właściciele (kiedy uzdrowisko było własnością prywatna), lekarz urzędujący w uzdrowisku oraz przedstawiciele samorządu gminnego: wójt gminy lub burmistrz miasta, na których obszarze znajdowało się uzdrowisko częściowo lub w całości, oraz delegaci rad gminnych i miejskich, w liczbie uzależnionej od liczby mieszkańców uzdrowiska.

Rangę ówczesnych komisji uzdrowiskowych podnosił fakt, że mogły one samodzielnie podejmować uchwały, które powzięte w obecności co najmniej połowy członków zachowywały ważność, a w niektórych kluczowych dla uzdrowiska sprawach uzyskiwały natychmiastowo moc obowiązująca, o ile delegat starostwa lub - w sprawach sanitarnych - lekarz powiatowy nie zgłosili sprzeciwu. Komisja była organem uchwałodawczym, wykonanie uchwał powierzano zaś wydziałowi wykonawczemu (zarządowi). Można zauważyć - analizując profil ustrojowy pierwszych komisji uzdrowiskowych - osobliwy dualizm organów kolegialnych o cechach podobieństwa do struktury samorządu terytorialnego, w której funkcjonują dwa organy kolegialne (jak w Polsce przed 2002 r.). Kompetencyjnie i zadaniowo komisje uzdrowiskowe były organami kontroli stanu sanitarno-budowlanego uzdrowiska, ale pod względem organizacyjnym działały w formule przypominajaccej ustrojowo samorząd terytorialny.

Obecna pozycja ustrojowoprawna komisji uzdrowiskowych w niczym nie przypomina dawnych komisji uzdrowiskowych - odrębność gmin uzdrowi- 
skowych polega na tym, że rada gminy ma obowiązek powołać obowiązkowo komisję uzdrowiskowa, jako trzecia - obok komisji rewizyjnej i komisji skarg wniosków i petycji - komisję obowiązkową w gminie. Podstawy do powołania tej komisji nie stanowi u.s.g., a ustawa odrębna, dlatego też można ją określać mianem quasi-obligatoryjnej ${ }^{21}$. Niezależnie jednak od podstawy prawnej powołania tych komisji sa one w gminach uzdrowiskowych dodatkowym organem wewnętrznym o charakterze obowiązkowym. Ich sposób kreacji musi uwzględniać obydwie regulacje, ale ustawa szczególna nie przewiduje tu własnych postanowień, z wyjątkiem ogólnego stwierdzenia, że przedmiot jej działania oraz skład osobowy określa rada gminy. Dlatego też należy posiłkować się ustawą podstawową (art. 21 u.s.g.), z której wynika, że stała komisję uzdrowiskową rada gminy może powołać ze swojego grona, ale w jej posiedzeniach mogą uczestniczyć - zabierając głos w dyskusji i składając wnioski bez prawa udziału w głosowaniu - radni, niebędący jej członkami.

Komisja uzdrowiskowa ma w świetle art. 47 ust. 2 status organu opiniodawczo-doradczego rady gminy w sprawach dotyczących uzdrowiska oraz obszaru ochrony uzdrowiskowej. W tym miejscu warto przypomnieć pogląd doktryny prawa administracyjnego, według którego tylko treść stanowiska wyrażona w formie uzgodnienia wiąże organ prowadzący postępowanie główne ${ }^{22}$, opinia zaś nie ma charakteru prawnie wiążącego, pozwalając na weryfikację i korektę postanowień dokumentu głównego (w tym przypadku uchwał rady gmin w sprawach dotyczacych uzdrowisk). Opinie komisji uzdrowiskowych dają możliwość swoistej redefinicji treści interesu publicznego w zakresie zadań wykonywanych przez te komisje. Ich katalog jest otwarty i obejmuje wyrażanie opinii w szczególności na temat: 1) projektu operatu uzdrowiskowego; 2) projektu statutu uzdrowiska lub statutu obszaru ochrony uzdrowiskowej; 3) projektów miejscowych planów zagospodarowania przestrzennego obejmujacych tereny wchodzace w skład stref ochrony uzdrowiskowej; 4) gminnych programów ochrony środowiska oraz 5) projektów programów zamierzeń inwestycyjnych gminy dotyczących obszaru uzdrowiska oraz obszaru ochrony uzdrowiskowej. Poza tymi zadaniami rada gminy uzdrowiskowej może określić inne zadania komisji uzdrowiskowej. Dla prawidłowości postępowania w powyższych sprawach wydanie opinii przez komisję uzdrowiskową jest obowiązkowe; choć sama opinia nie wiąże organu głównego, nieuwzględnienie jej w powyższych sprawach nie znajduje uzasadnienia ustrojowego. Nie taki - jak się wydaje - był cel ustawodawcy, aby powołana stała komisja uzdrowiskowa miała wyłącznie charakter pomocniczy, a jej ocenę w poważnych merytorycznie sprawach można było pominać. Intencją ustawodawcy było obowiązkowe powołanie komisji uzdrowiskowych w każdej gminie posiadajacej status uzdrowiska, komisji działającej przez cały okres kadencji rady i wspierającej ją we wszystkich ważnych z punktu widzenia ochrony środowiska i przestrzeni sprawach.

\footnotetext{
21 Augustyniak (2012): 141-142.

22 Borkowski (1996): 468.
} 


\section{STATUT UZDROWISKA}

Kolejną odrębnościa gmin uzdrowiskowych jest obowiązek posiadania dodatkowego statutu - statutu uzdrowiska. Gmina uzdrowiskowa dysponuje, jak każda gmina statutem gminy, ale jako gmina szczególna także statutem uzdrowiska. Statut gminy uzdrowiskowej nie różni się zasadniczo od statutu gminy „standardowej”, z wyjątkiem konieczności umieszczenia w nim odrębnej jednostki redakcyjnej poświęconej komisji uzdrowiskowej. Przepisy statutowe dotyczace komisji uzdrowiskowej określają zwykle, że do komisji uzdrowiskowej stosuje się odpowiednio postanowienia statutu dotyczące organizacji i funkcjonowania komisji stałych (np. co do zasad wyboru przewodniczacego komisji). Niekiedy - w ramach samodzielności statutowej gmin - wprowadza się pewne odrębności. Ponieważ u.l.u.g.u. dopuszcza możliwość udziału w komisji uzdrowiskowej osób spoza rady, statut gminy uzdrowiskowej powinien tę materię doprecyzować (dodając np., że w pracach komisji uzdrowiskowej z głosem doradczym mogą uczestniczyć specjaliści i eksperci z dziedziny lecznictwa uzdrowiskowego, urbanistyki, planowania przestrzennego i ochrony środowiska). Regulacje statutowe moga rozszerzyć katalog zadań komisji uzdrowiskowej, w zależności od istniejącego na danym ternie faktycznego zapotrzebowania. Statut nie może jednak wbrew u.l.u.g.u. „zamknąć” katalogu zadań komisji uzdrowiskowej.

Odrębnym przepisem statutowym w gminach uzdrowiskowych jest statut uzdrowiska lub statut obszaru ochrony uzdrowiskowej. Statut uzdrowiska jest kolejnym, obok operatu uzdrowiskowego, dokumentem o istotnym znaczeniu dla powstania i funkcjonowania uzdrowiska ${ }^{23}$. W świetle art. 41 ust. 3 u.l.u.g.u. rada gminy powinna go uchwalić w terminie 30 dni od dnia wejścia w życie rozporządzenia Rady Ministrów w sprawie nadania danemu obszarowi statusu uzdrowiska lub statusu obszaru ochrony uzdrowiskowej, po potwierdzeniu przez ministra zdrowia w drodze decyzji spełnienia warunków koniecznych do nadania statusu uzdrowiska. Analiza wybranych statutów uzdrowisk prowadzi do wniosku, że koncentrują się one głównie na warstwie materialnoprawnej. Jest to zrozumiałe, skoro ustrój uzdrowiska jako jednostki został określony w statucie gminy. Tym samym do materii statutu uzdrowiska pozostaja sprawy podziału uzdrowiska na strefy, z uwzględnieniem części graficznej i określenia w ramach poszczególnych stref obowiązujących w nich zakazów zgodnie z indywidualnymi uwarunkowaniami. Kwestia, czy regulacja statutowa może zaostrzać zakazy określone przez ustawodawcę powszechnego w art. 38 ust. 1 ww. ustawy, jest zagadnieniem, które należy rozważyć na podstawie oceny konkretnych uregulowań aktu prawa miejscowego ${ }^{24}$. Regulacja zakazów w art. 38 ust. 1 u.l.u.g.u. nie wyłącza statutowej regulacji zakazów. Ustawa w art. 41 ust. 1 i 2 upoważnia radę gminy do samodzielnego uregulowania czynności zabronionych wynikających z indywidualnych uwa-

${ }^{23}$ Trzcińska (2018): 159-160.

${ }^{24}$ Wyrok NSA z 2 grudnia 2010 r., II OSK 1990/10, Lex nr 786780. 
runkowań uzdrowiska ${ }^{25}$. Podsumowując ten wątek, posiadanie przez gminę uzdrowiskową dwóch statutów: statutu gminy i statutu uzdrowiska świadczy o istotnej odrębności o charakterze ustrojowym, choć - jak zostało zaznaczone - statut uzdrowiska, pozostając przepisem ustrojowym, posiada swoiste, materialnoprawne cechy.

\section{ODRĘBNA KONSTRUKCJA NADZORU}

Następną odrębnością gmin uzdrowiskowych zapowiedzianej w u.s.g. jest konstrukcja nadzoru. W tym miejscu wypada przypomnieć, że nadzór stanowi jedno z podstawowych pojęć prawa administracyjnego i w swej typowej postaci występuje w układzie organów zdecentralizowanych ${ }^{26}$. W gminie uzdrowiskowej, jak w każdej gminie, wojewoda pełni rolę organu nadzoru ogólnego, a regionalna izba obrachunkowa - nadzoru szczególnego, ale gmina ta, ze względu na swoją specyfikę i szczególność zadań, podlega nadzorowi organów fachowych, przede wszystkim zaś ministra właściwego do spraw zdrowia w zakresie spełniania przez jej obszar albo jego część wymagań określonych w ustawie. W związku z tym ciąży na niej ustawowy obowiązek sporządzenia i przedstawienia, nie rzadziej niż raz na 10 lat, ministrowi właściwemu do spraw zdrowia operatu uzdrowiskowego.

Występowanie, jak wspomniano, „ponadstandardowych” zadań własnych, skupionych wokół prowadzenia lecznictwa uzdrowiskowego generuje konieczność wzmocnienia nadzoru fachowego zarówno podmiotowo, przez przyznanie kompetencji nadzorczych ministrowi zdrowia, jak i przedmiotowo. Wojewoda zaś oprócz wykonywania nadzoru ogólnego sprawuje nadzór nad lecznictwem uzdrowiskowym prowadzonym przez zakłady lecznictwa uzdrowiskowego na obszarze województwa przy pomocy naczelnego lekarza uzdrowiska (art. 17 ust. 2 u.l.u.g.u.). Naczelny lekarz uzdrowiska sprawuje nadzór nad jakościa świadczeń opieki zdrowotnej udzielanych przez zakłady lecznictwa uzdrowiskowego.

Analiza przepisów poświęconych nadzorowi nad lecznictwem uzdrowiskowym pozwala na postawienie tezy, że środki nadzorcze ministra zdrowia nie maja jednolitego charakteru. Można podzielić je na środki informacyjne (np. żądanie udostępnienia dokumentów związanych z działalnością zakładów lecznictwa uzdrowiskowego oraz zapoznawania się z ich treścią lub żądanie przekazania wszelkich informacji i wyjaśnień dotyczących działalności zakładów lecznictwa uzdrowiskowego), ocenne (np. ocena zgodności lecznictwa uzdrowiskowego z kierunkami leczniczymi), kontrolne (np. przeprowadzanie kontroli na terenie zakładów lecznictwa uzdrowiskowego i żądania wyjaśnień potrzebnych dla oceny ich działalności i jakości świadczeń opieki zdrowotnej oraz funkcjonowania zakładów lecznictwa uzdrowiskowego) oraz o charakterze

25 Wyrok WSA we Wrocławiu z 8 grudnia 2011 r., IV SA/Wr 504/11, Lex nr 1155180.

${ }^{26}$ Kosiński (2006): 102 n. Na ten temat zob. Dolnicki (1993). 
władczym (np. wydawanie zaleceń pokontrolnych mających na celu usunięcie stwierdzonych nieprawidłowości czy też wydawanie w miarę potrzeby decyzji administracyjnych nakazujących usunięcie stwierdzonych nieprawidłowości).

Wyżej wskazane środki nadzoru nie dotycza - rzecz jasna - działalności gminnej, lecz działalności uzdrowiskowej, przy czym obydwa zakresy działalności moga się pokrywać (np. planowanie przestrzenne gmin jako zadanie własne oddziałuje na sytuację planistyczna uzdrowiska). Kompetencje nadzorcze wojewody w aspekcie legalności rozciagają się przy tym na standardowe zadania wykonywane przez gminę uzdrowiskowa (np. w zakresie ochrony środowiska czy gospodarki terenami) oraz na zadania o charakterze uzdrowiskowym. Można więc skonstatować, że model nadzoru sprawowanego przez wojewodę nad gminą uzdrowiskową ma charakter dualistyczny.

Reasumując, tę część rozważań, odrębna konstrukcja nadzoru nad gminą uzdrowiskowa polega na tym, że jej działalność podlega nadzorowi ogólnemu, wykonywanemu przez wojewodę, fachowemu - wykonywanemu przez regionalną izbę obrachunkową (np. w zakresie opłat uzdrowiskowych) oraz specjalnemu - wykonywanemu przez organ quasi-nadzorczy, tzn. ministra.

\section{ZAKOŃCZENIE}

Podsumowując powyższe rozważania, należy stwierdzić, że gminy uzdrowiskowe cechuje kilka odrębności ustrojowych. Odrębności te wynikają ze szczególnego charakteru tych gmin, zdeterminowanego występowaniem zadań publicznych związanych z prowadzeniem lecznictwa uzdrowiskowego. Można zauważyć, że pierwotnym czynnikiem, który decyduje o powstaniu gminy o statusie uzdrowiska, jest posiadanie naturalnych surowców leczniczych i możliwość ich wykorzystania na danym terenie. Tworzy się w ten sposób swoisty zasób infrastruktury przeznaczonej do prowadzenia lecznictwa uzdrowiskowego, a w miarę rozwoju uzdrowiska zasób społeczny, który stanowia turyści i kuracjusze. Te dwa czynniki: surowcowy i ludzki, wraz z koniecznością zapewnienia bardzo dobrych warunków sanitarnych i środowiskowych stanowia filary gminy uzdrowiskowej. Ustawodawca zdecydował, że aby prawidłowo zarządzać tymi filarami, na ustrój gminy należy nałożyć dodatkowy „pancerz”, celem zabezpieczenia wykonywania tych wyjątkowych, związanych z możliwością leczenia zadań.

Marta Woźniak

Uniwersytet Opolski

martawozniak1@o2.pl

https://orcid.org/0000-0003-0021-6760

Augustyniak, M. (2012). Organizacja i funkcjonowanie rady gminy. Warszawa.

Borkowski, J. (1996). Kodeks postępowania administracyjnego - Komentarz. Warszawa.

Dolnicki, B. (1993). Nadzór nad samorządem terytorialnym. Katowice. 
Dolnicki, B. (2016). Samorząd terytorialny. Warszawa.

Dudar, G. (2006). Opłata uzdrowiskowa - problemy praktyczne. Przegląd Podatków Lokalnych i Finansów Samorządowych 6: 8-17.

Korczak, J. (2018). Gmina uzdrowiskowa w prawodawstwie polskim. Opolskie Studia Administracyjno-Prawne 16, 1(1): 99-118.

Kosiński, C. (2006). Nadzór administracyjny jako element determinujący zakres samodzielności jednostek samorządu terytorialnego, [w:] C. Kosiński (red.), Nadzór administracyjny. Od prewencji do weryfikacji. Wrocław: 79-116.

Leoński, Z. (2006). Samorząd terytorialny w RP. Warszawa.

Maciejewski, T. (2002). Historia administracji. Warszawa.

Nowak-Far, A. (2010). Miejscowości uzdrowiskowe w Austrii, Czechach, Niemczech i na Słowacji: status prawny i regulacyjne determinanty funkcjonowania. Studia z Polityki Publicznej 2(18): 37-58.

Paczuski, R. (1991). Zagadnienie odrębności prawnoustrojowej samorządów zarządzających sprawami uzdrowisk. Ruch Prawniczy, Ekonomiczny i Socjologiczny 53(2): 85-95.

Paczuski, R. (2015). Ochrona zasobów leczniczych środowiska Rzeczypospolitej Polskiej jako jedna z podstawowych form zarządzania ochroną środowiska przy respektowaniu zasady zrównoważonego rozwoju. <https://repozytorium.uwb.edu.pl/jspui/bitstream/11320/3440/1/ BSP_18_2015_Paczuski.pdf>.

Sikora, K. (2014). Szczególny status gmin uzdrowiskowych w Polsce. Studia Iuridica Lublinensia 23: $107-124$.

Trzcińska, D. (2018). Ochrona środowiska a status uzdrowiska w świetle prawa planowania przestrzennego. Opolskie Studia Administracyjno-Prawne 16, 1(1): 155-164.

\section{THE DISTINCT LEGAL STATUS OF SPA COMMUNES}

\section{Sum mary}

The aim of this article is to present the distinct legal status of a spa commune (gmina) in Poland. With this aim, the considerations focus on the development of legislation on spa communes, which dates back to 1922. Nevertheless, the basis for the considerations relates to the current legal situation. In her article, the author indicates that a spa commune is a municipality of the dual legal model: standard and special. The differences are connected with a number of aspects: the area, name, tasks and spa fees charged, the spa commission, the statute and supervisory activity. They result from the specific character of these communes, which is determined by the presence of public tasks connected with providing treatment in health resorts. The conclusion is that there are two pillars on which a spa commune rests: the resource-related aspect - based on the necessity of providing very good sanitary and environmental conditions in resorts, and the human aspect constituted by tourists. For these pillars to be managed in a proper way, the legislator has decided to grant separate legal status to these communes.

Keywords: spa commune (gmina); tasks; spa fee charged; spa commission; the statute; supervisory activity 
